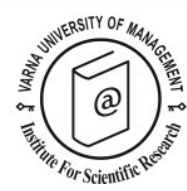

\title{
Sustainability disclosure and a legitimacy crisis: Insights from two major cruise companies
}

\author{
Selena Aureli ${ }^{1 *}$, Renato Medei ${ }^{2}$, Enrico Supino ${ }^{3}$ and Claudio Travaglini 4
}

Received: 07/10/2016 Accepted: 05/04/2017

\begin{abstract}
1 University of Bologna, Department of Management and Centre for Advanced Studies in Tourism, Rimini Campus, via Angherà, 22 - Rimini, Italy; tel: +39 0541 434230, e-mail: selena.aureli@unibo.it

2 University of Bologna, Centre for Advanced Studies in Tourism, Rimini Campus, via Angherà, 22 - Rimini, Italy; tel: +39 0541 434086; e-mail: renato.medei@unibo.it

3 University of Bologna, Department of Management and Centre for Advanced Studies in Tourism, Rimini Campus, via Angherà, 22 - Rimini, Italy, tel: +39 051 2098069; e-mail: enrico.supino@unibo.it

${ }^{4}$ University of Bologna, Department of Management and Centre for Advanced Studies in Tourism, Rimini Campus, via Angherà, 22 - Rimini, Italy; tel: +39 0541 434111; e-mail: claudio.travaglini@unibo.it

* Corresponding author
\end{abstract}

\begin{abstract}
The main aim of this paper is to analyse company sustainability disclosure in case of a legitimacy crisis. This work sets out to investigate how the negative externalities of an event reported widely in the media, such as the sinking of the Costa Concordia class cruise ship, have affected sustainability communication, for not only Carnival Corporation \& PLC (the parent company of Costa) but also its most direct competitor Royal Caribbean Cruises Ltd. The paper relies on text analysis focusing on the sustainability reports of the two major companies (in terms of market share) in the cruise sector. Authors compared the reports of Carnival Corporation \& PLC and its most direct competitor for a five-year period using text mining techniques. Results indicate that an event with social and environmental negative externalities, dominating international media and capable to bring discredit in the eyes of stakeholders, generates a change in the sustainability communication of both companies. Thus, repercussions are larger than one might suppose. Companies reduced the amount of information disclosed as a strategy to influence the perception of their audience, demonstrating that the provision of justifications, explanations and announcements of new sustainable policies (which increase the quantity of information) is not a predictable reaction. This paper undertakes empirical research on the sustainability reports of cruise line companies - which have been largely overlooked - and contributes to better understand company sustainability reporting praxis after an industrial disaster.
\end{abstract}

(C) 2017 Varna University of Management. All rights reserved

Keywords: Cruise lines, Sustainability reports, Text mining, Legitimacy theory, Tourism, Industrial Disaster.

Citation: Aureli, S., R. Medei, E. Supino, C. Travaglini (2017) Sustainability disclosure and a legitimacy crisis: Insights from two major cruise companies. European Journal of Tourism Research 17 pp. 149-163

\section{Introduction}

The cruise sector is one of the fastest growing and most dynamic segments of the entire tourism and leisure travel market (Cruise Market Watch, 2015; Xiao Dong, Xiao Rong, \& 
Xue Gang, 2015). However, cruise holidays are labelled as a unsustainable typology of tourism (Butt, 2007). The growth of the cruise sector (for example, the European cruise market grew from 3.4 million passengers in 2006 to 5.5 million passengers in 2010 according to CLIA Europe Statistics 2014) highlights a serious problem of sustainability in terms of negative environmental and social impact: the growing demands from new passengers requires the construction of increasingly large ships, which in turn have increasing impacts on the marine environment and the cruise destinations (Bonilla-Priego, Font, \& Pacheco-Olivares, 2014; Brida \& Zapata, 2009; Johnson, 2002; Klein, 2011; Wood, 2000).

The categories of eco-justice and ecoefficiency (Bebbington \& Gray, 2001; Young \& Tilley, 2006) are hard to apply to the cruise context, when we consider that, during navigation, a ship stops in a port for a limited period to load goods and offload waste. A negative pay-off is therefore generated between the resources taken and the waste left, producing inefficiency in terms of sustainability. Moreover, local communities perceive a worsening of their own quality of life when they encounter affluent tourists that waste the local scarce resources (Jordan, Vogt, \& DeShon, 2015). Actually, cruise tourists and owners are located in countries in the north of the world, while the most popular routes are those of the southern seas (i.e. Caribbean islands), giving rise to further disparity in the distribution of wealth and negative externalities. Additional social concerns relate to changes to indigenous value systems, traditional lifestyles and behaviours at ports of call, to food safety and health for passengers and to working conditions for crew members (Jones, Hillier, \& Comfort, 2016).

In response to the increasingly strict environmental regulations and the social and political pressure concerning these topics, cruise companies have enhanced the level of voluntary reporting on social, environmental and economic responsibilities, producing report, which are usually available on corporate institutional websites (Jones et al., 2016; Morhardt, 2010).
As explained by Bebbington, Larrinaga, and Moneva (2008) and in line with the theoretical basis of the legitimacy theory (Adams, Hill, \& Roberts, 1998; Deegan, 2002), voluntary reporting on sustainability topics is driven by the aim of managing corporate reputation and legitimacy, as well as the risk linked to negative events. Thus, sustainability reports can be used as a managerial tool and their content changed according to the companies' specific purposes. For the above-mentioned reason, it is worthwhile to understand what happens to sustainability communication when a company is responsible for an event with highly negative repercussions on both the environment and the society. Previous studies have attempted to describe this situation (Harlow, Brantley, \& Harlow, 2011; Lee \& Blanchard, 2012; Matacena, 2010; Michelon, 2012; Sorensen, 2012; Volo \& Pardew, 2013) but there are no common conclusive findings. This work aims to contribute to existing research using the case of a huge event with negative externalities and widely reported in the media, such as the sinking of the ship named Costa Concordia, to analyse possible changes occurred in the sustainability communication of its holding company Carnival Corporation \& PLC (CCL) and its most direct competitor Royal Caribbean Cruises Ltd (RCL).

The analysis of the sustainability praxis before and after the wrecking of Costa Concordia is pointed out to answer the following questions:

- RQ1: Does the sustainability disclosure of $\mathrm{CCL}$ change after the occurrence of the industrial disaster of Costa Concordia?

- RQ2: (To what extent) does the industrial disaster affect the sustainability disclosure of CCL's main competitor?

The research focuses on $\mathrm{RCL}$ and $\mathrm{CCL}$ because these two companies alone control around two thirds of the worlds' passenger capacity. According to Cruise Market Watch (2015), CCL has the majority of the market shares with $48 \%$ of passengers and $42 \%$ revenues, while $\mathrm{RCL}$ ranks second with $17 \%$ of passengers and $14 \%$ of revenues worldwide.

The wrecking of the Costa Concordia is an important event for the legitimacy of the whole 
sector because it is not just a service failure (Skaalsvik, 2011); it is a tragic event affecting both the passengers and the environment and which implies the responsibility of the crew and the inadequate management of the organisational procedures of navigation and human and environmental safety. The episode represents the paradigm of the crises and it had a huge media impact on the cruise sector due to the way in which it occurred. We have therefore hypothesised the need for managers to re-establish the trust in the ability of these companies and their personnel to manage social and environmental sustainability matters through a modified communication in sustainability documents.

The theoretical basis of this research is presented in the second paragraph. The third paragraph introduces the concept of text mining, a text analysis method used to automatically detect hidden information in data (Tan \& Lambrix, 2009) to create interpretations or analytical models that explain trends in text data (Romero, Espejo, Zafra, Romero, \& Ventura, 2013; Romero, Ventura, \& García, 2008). The results of the analysis are presented in paragraph 4 . The final paragraph examines the evidence obtained from data analysis, the implications, limitations and possible future developments of the research.

\section{Literature Review \\ Sustainability concerns and sustainability reporting of cruise companies}

As predicted by Page (1987) in the late 1980s, academic research on the cruise sector has seen rapid development over the past few years, in step with the growth of the sector itself. Among others, a topic gaining in importance is the relationship between the cruise business and society (Papathanassis \& Beckmann, 2011). The impact of cruise lines on people and the society is becoming a relevant issue because the relative increase in the size of the ships and the volume of visitors crowding the ports and the nearby tourist destinations, has brought new demands on infrastructure (Jones et al., 2016). The local authorities and port management authorities are faced with the need to tackle a situation which generates not only economic problems (e.g. assessing the costs and benefits of port modernisation projects), but also has huge social and environmental repercussions.

The cruise ship is not a closed system. When it docks, it exchanges resources and waste with local operators, causing various environmental and social problems (Brida \& Zapata, 2009; Butt, 2007; Cloesen, 2003). Its arrival implies an over-use of water and other scarce resources, which are supplied to the ship and thus taken from the local population (BonillaPriego et al., 2014; Jordan et al., 2015). Often the ship transit corridors are created to the detriment of the coral reefs, the destruction of which leads to a reduction in marine life and therefore damages the local fishing and other connected economies (Erftemeijer, Riegl, Hoeksema, \& Todd, 2012). The socioenvironmental impact of cruises is huge, above all when the itineraries cover small islands and places marked by a delicate ecosystem (Cloesen, 2003; Dale \& Robinson, 1999). Moreover, the presence of the ship and its passengers can trigger psychological and social problems for the local communities, which encounter wealthy tourists wasting resources and may perceive a worsening of their own quality of life due to the increase in this kind of tourism (Jordan et al., 2015). Lastly, cruise tourism is not always economically viable for the destinations it reaches. As demonstrated by the case of the Caribbean (Bresson \& Logossah, 2011), this type of tourism reduces the number of visitors staying locally, and therefore replaces (rather than integrates) traditional tourism which usually has greater positive externalities on the local context. Equally important is the danger deriving from the creation of asymmetric power structures, where local operators and the government authorities of the countries of destination, often with scarce financial resources, depend on the cruise operators and other foreign suppliers to create infrastructure and develop local tourism (Jordan et al., 2015; Lee, Hampton, \& Jeyacheya, 2015; Lester \& Weeden, 2004).

Cruise companies seem to be quite aware of the impact of their activities on the society, environment and economy of the countries of destination as well as the countries of origin. For example, in their analysis of materiality, 
several issues are acknowledge by RCL and CCL (Jones et al., 2016). However, to tackle the demands for closer attention to social aspects, these companies are more prone to running philanthropic projects, funding schools and hospitals, aiming to ensure the social legitimacy of their activities rather than to implement long-term sustainable policies (Weeden, 2015). With reference to the whole sector, the general level of sustainability disclosure is still low (Font, Guix, \& BonillaPriego, 2016). The study carried out by BonillaPriego et al. (2014) on 29 cruise companies indicates that less than half of these produce a sustainability report. The major international brands are more willing to publicly communicate the adoption of CSR policies in specific reports, while the other companies mainly use their own website, where the information transmitted is however quite scarce (De Grosbois, 2016b). There is therefore a significant gap between the majority of cruise operators and the few best in class (i.e. RCL and $\mathrm{CCL}$ ), who follow the Global Reporting Initiative (GRI) guidelines in drafting their reports (Jones et al., 2016) and have received awards and recognitions, such as the inclusion in the Dow Jones Sustainability Index (DJSI).

As regards the topics covered, the reports focus on environmental aspects, such as water and fuel consumption and gas emissions, aiming primarily to identify cost reduction practices. Information regarding the company relationship with society mainly refers to compliance with international rules, while there is little attention to the local communities where the ships run. The aspects concerning shareholders receive attention, while reports scarcely consider other stakeholders' demand. The categories of weaker stakeholders do not seem able to exert sufficient pressure on the companies surveyed. For example, issues of employment quality and diversity and accessibility are reported to a much lesser extent (De Grosbois, 2016a, 2016b).

\section{Legitimacy theory and changes in the level of disclosure after a crisis}

Cruise company sustainability reporting appears to be interpretable mainly in the light of the legitimacy theory (Bonilla-Priego et al., 2014). The legitimacy theory, while quite similar and often used in a complementary manner to the stakeholder theory (Deegan, 2002), ascribes the disclosure of socio-economic information to the will of managers to activate communication strategies in order to acquire, maintain or regain the legitimacy of their business in society (Cho \& Patten, 2007). Legitimacy and stakeholder theory are both socio-political, as they are linked to the relationship between companies and members of the external society (Freeman, Rusconi, Signori, \& Strudler, 2012). They contrast purely economic theories, such as the agency theory and the resource-based view theory, according to which information is disclosed because it is economically rational (Cormier, Magnan, \& Van Velthoven, 2005).

Used from the 1970s to the present (Dowling \& Pfeffer, 1975; Sethi, 1979), the roots of the legitimacy theory lie in the works of Weber and Parsons (Suchman, 1995). This theory represents one of the most common perspectives used in corporate social responsibility accounting and reporting literature to explain the adoption of social reporting practices by organizations (Hopwood, 2009; Mahadeo, Oogarah-Hanuman, \& Soobaroyen, 2011; Monfardini, Barretta, \& Ruggiero, 2013), although some authors have underlined the need for further study (Deegan, 2002; Tilling, 2004). The underlying idea is that companies need to establish congruity between the social values associated to their activities and the commonly accepted rules of conduct in the broader social system they belong to (Cho \& Patten, 2007). To run their business, companies conclude a kind of "social contract". When there is a lack of congruity because society's expectations are not satisfied, there is a problem of legitimacy for the companies' activities, which could compromise the abovementioned contract and consequently make it impossible for the company to obtain the financial, human and environmental resources which it needs (Summerhays \& De Villiers, 2012). Following the strategic approach (Dowling \& Pfeffer, 1975; Tregidga, Milne, \& Kearins, 2006), which conceives legitimacy as an aspect which can in some way be controlled by the managers, it is assumed that companies can alter their status of legitimacy, mainly through disclosure, which affects the 
perception of the parties targeted by the disclosure itself (Aerts \& Cormier, 2009).

When an accident, event or critical situation occurs, which may generate a problem of legitimacy, managers try to respond to the solicitations of external society - or those raised by the media (Brown \& Deegan, 1998; Gillet-Monjarret, 2015; Islam \& Deegan, 2010; Prokofieva \& Clark, 2014) - by introducing specific communication strategies. Various events can generate a legitimacy gap, from an accident with environmental or social repercussions (Deegan, Rankin, \& Voght, 2000 ), to the demand or pressure from government authorities to adopt new social standards and practices (Ahmed Haji, 2013; De Villiers \& Van Staden, 2006; Deegan \& Rankin, 1996), from a legal action taken against the company, to specific activities undertaken by NGOs (Deegan \& Islam, 2014; Deegan et al., 2000). Studies that relate socio-environmental disclosure to a critical event mainly concern companies in the Oil \& Gas sector (Cho, 2009; Islam \& Islam, 2011; Summerhays \& De Villiers, 2012) as well as sectors that are more vulnerable to environmental risk such as utilities and the chemical sector, or again companies exposed to reputational risk, such as consumer goods manufacturers and financial corporations (Gillet-Monjarret, 2015). Equally relevant is the research in the mining (De Villiers \& Van Staden, 2006) and clothing sectors (Islam \& Deegan, 2010), whose operations usually located in developing countries are criticised for their poor working conditions which do not always guarantee the respect of human rights.

Applying the legitimacy theory to analysing corporate reports (mainly annual reports and sustainability reports) suggests that in the event of an accident or other negative event, the company involved reacts to repair legitimacy either providing explanations or excuses to what happened or denying the problem and its responsibility for the event (Suchman, 1995). In the first case, the company opts for an image enhancement strategy translating into the increase in information on the positive results achieved and company's social values. In the last case, the company opts for a disclaimer strategy, which consists in stating that the company is not responsible for the accident or event and therefore for its negative consequences. In both cases, the response usually leads to an increase in the amount of information produced (Cho, 2009; De Villiers \& Van Staden, 2006; O'Donovan, 2002; Summerhays \& De Villiers, 2012). The underlying idea is that the greater the concern expressed by the community, the more extensive company disclosure about social and environmental aspects will be (Brown \& Deegan, 1998). Studies often use quantitative measures to evaluate disclosure, such as the number of sentences or words concerning social and environmental issues, calculating the percentage increase in information provided compared to the total number of pages in the corporate reports (Cho, 2009; Hooks \& van Staden, 2011; Islam \& Deegan, 2010). Modifications to corporate disclosure do not however concern only the company that caused the accident, as its direct competitors and all businesses in the sector tend to disclose more social and environmental information (Summerhays \& De Villiers, 2012). According to Islam and Deegan (2010), all major players of the sector can suffer the negative consequences of the incorrect conduct of a single company.

\section{Methodology}

The increasing spread of non-structured corporate reporting (like the diffusion of social reports, reporting for intangible assets and the publication of greenhouse gas emissions reports) has led to the development of several methods that extract information on the meaning of the disclosure documentation. In relation to sustainability reporting, different methods for textual analysis were applied in previous work, with a large preference for content analysis (Aureli, 2017; Cho, 2009; Cho \& Patten, 2007; De Villiers \& Van Staden, 2006). Differently, this paper applies a newer and emergent technique of analysis named text mining.

On one hand, content analysis helps investigate not only the quantity but also the quality of corporate communication, providing indications on the type of legitimacy strategy adopted by companies (Michelon, 2012). Moreover, using content analysis it is possible 
to distinguish between general information and specific information, and understand the possible interactions between the different topics covered by socio-environmental communication (De Villiers \& Van Staden, 2006). On the other hand, this technique involves one important limitation: the difficulty in comparing studies. Authors often use different coding schemes, adapting them to the different research objectives and the various aspects of corporate communication they aim to analyse (Cho, 2009; Cho, Patten, \& Roberts, 2006). Adaptations are also made to take into account the special features of the investigated sector, which implies different interlocutors and sustainability practices (Bonilla-Priego et al., 2014). Even when the construction of key concepts starts from previous studies or previously used indices (De Villiers \& Van Staden, 2006), the ability to generalise the results is very limited because the presence of human coders (i.e. the authors) may involve some subjectivity.

Text mining, instead, is an automated text analysis method (i.e. performed by a software) for researching and extracting models, indications, trends and rules in non-structured texts, such as text documents, HTML files, chat messages and e-mails (Feldman \& Dagan, 1995; Fuller, Biros, \& Delen, 2011; He, 2013; Özyurt \& Köse, 2010). Text mining can be used systematically to highlight, extract, manage, integrate and exploit the information, which can be taken from text documents to measure hidden information in data (Fu-Ren, Lu-Shih, \& Fu-Tai, 2009; Loh, Wives, \& de Oliveira, 2000). Text mining, started in 1960s, became popular in 1990s, when it was included the primary field of Information System (Dörre, Gerstl, \& Seiffert, 1999). This technique takes out knowledge from text documents in two different stages: text pre-processing and knowledge extraction. In the text pre-processing phase, software converts unstructured data into a documentterm matrix, while the knowledge extraction involves data mining. Pre-processing a corpus of textual data consists in tokenization, stop words removal and stemming, followed by the formulation of a document-term matrix, as proposed by Salton and McGill (1986); this stage is fundamental in text mining, because high-quality of pre-processing produces high- quality knowledge (Uysal \& Gunal, 2014). Text mining application could be summarized in five activity categories (Kumar \& Ravi, 2016): Classification, Clustering, Association Rule Mining (ARM), Text summarization and Topic detection/ identification. Textual data are classified and codified by a software. The introduction of Machine Learning algorithms for text mining reduces human intervention and time to process the text. Compared to content analysis the absence of human coder increases the reliability of results (Milne \& Adler, 1999) and the quality of mining.

Although text mining is an emergent technique in the companies' report analysis, it has already been applied in the past. Kloptchenko et al. (2004) analysed the information in the annual report and reached the conclusion that the text contents can predict variations in the financial performance of companies. Liew, Adhitya, and Srinivasan (2014) applied text mining to investigate topics of sustainability disclosure in the chemical sector, while (Aureli, Medei, Supino, \& Travaglini, 2016) used text mining to search for changes in the sustainability reports of six companies involved in industrial disasters.

In the present study, text mining is used to analyse the content of sustainable reports of two cruise companies after the sinking of Costa Concordia on January 12, 2012. This fact represents a striking example of an industrial disaster that created a legitimacy crisis for the whole sector (as demonstrated by the worldwide media attention) and is likely to affect external corporate communication.

The impact of the Costa industrial disaster on CCL's and RCL's sustainability reports was analysed preparing a wordlist of terms relating to sustainability and highlighting if and how the relative frequency of the vocabulary compared to the total number of words changed over the years. The wordlist was constructed based on the Global Reporting Initiative (GRI) guidelines, version 3, to which the analysed reports expressly refer. The GRI document underlines seven relevant aspects or dimensions for corporate sustainability disclosure: Economic (EC), Environmental (EN), Labour Practices (LA), Human Rights (HR), Product 
Responsibility (PR), Society (SO) and Strategy (ST). The wordlist was then structured on the same distribution, and was constructed by extracting from the GRI document the paragraphs relative to each dimension and subjected to analysis, in an unequivocal manner including the words and strings in each section for which the probability of random inclusion in the document is less than $10 \%$. The wordlist (with a total of 130 terms) was enriched with synonyms, considered most suitable by the researchers according to the specific objectives of the research, from those given in the on-line dictionaries Thesaurus.com and Oxforddictionaries.com.

The corpus consisted of five sustainability reports for CCL and five for RCL. They were downloaded from the companies' web sites, and refer to the five-year period from 2009 to 2013. The first three reports of each series were disclosed before the disaster, the remaining two ones refer to the two-year period after the disaster. All the reports were certified by the GRI and are written in English. Sustainability reports from other cruise companies were not included in the corpus, in fact only $\mathrm{CCL}$ and $\mathrm{RCL}$ regularly produced reports during the considered period.

The text mining application to the corpus was organised into two stages. During the first stage, the documents were pre-processed, converted from PDF to plain text format to facilitate acquisition and reading by the software $\mathrm{R}$ and the temis application (BouchetValat \& Bastin, 2015). The text documents imported into the software were automatically processed to render the corpus uniform. In detail, all the words in lower case were converted to make them equivalent, and were then filtered to remove the "stop words", i.e. all the "functional" words with no meaning, such as articles, pronouns, adverbs and conjunctions. Thereafter the documents were cleaned of all punctuation, numerical values, graphic symbols and hypertext links. Finally, the words were stemmed, i.e. reduced to their root; the stemming process is used to trace variations of the same word to a stem, increasing the precision of the analysis and reducing variability and costs (Feldman \& Sanger, 2007; Weiss, Indurkhya, Zhang, \&
Damerau, 2010). Having ensured the uniformity of the single elements of the corpus, the text was converted into a word terms matrix, which summarises the occurrences of each word in the text. In the second stage, the number of times the words in the wordlist occurred was extracted from each report, calculating the relative frequency of each word. To reduce the risk of distortion due to the different lengths of the documents, the absolute frequencies were related to the total number of words in the document, excluding the stop words.

\section{Data analysis}

Based on the above-described explanations, this paragraph aims to compare the sustainability information produced by CCL and $\mathrm{RCL}$ in the years preceding and immediately following the Costa Concordia shipwreck. Table 1 shows the measurement of relative presence of the wordlist, for both companies, referring to the time period between 2009 and 2013, identified according to the decomposition of the concept of sustainability in the categories described in the previous paragraph.

If we consider all the categories of the wordlist, we can see that in the five-year period considered, the average value for $\mathrm{CCL}$ $(16.02 \%)$ is much higher than that of $\mathrm{RCL}$ $(11.06 \%)$, even though the value recorded in the last year $(13.16 \%)$ could lead us to think of a possible progressive decrease in this deviation. The same thing happens also referring to the single sustainability categories, with the exception of the Human Rights section, for which both values are around $0.5 \%$, and the Society section, in which the average value of RCL $(1.03 \%)$ is higher than CCL's one $(0.74 \%)$. The average values and other important parameters of the distributions presented in Table 1 are shown in Table 2. They can be useful in order to better evaluate the central tendency and the variability of the proposed relative disclosure measures with reference to their total level and the categories by which they were decomposed.

A first reflection on the level of sustainability disclosure can be done considering the totals obtained by summing all categories. Figure 1 shows overall trends of the relative presence of the wordlist for the two companies in the five- 
Table 1. Relative presence of the wordlist

\begin{tabular}{cccccccccc}
\hline Company & Year & EC & EN & HR & LA & PR & SO & ST & Total \\
\hline \multirow{6}{*}{ CCL } & $\mathbf{2 0 0 9}$ & $0.94 \%$ & $3.79 \%$ & $0.64 \%$ & $4.97 \%$ & $3.15 \%$ & $0.81 \%$ & $0.85 \%$ & $15.14 \%$ \\
& $\mathbf{2 0 1 0}$ & $1.36 \%$ & $5.43 \%$ & $0.50 \%$ & $3.47 \%$ & $3.09 \%$ & $0.70 \%$ & $1.65 \%$ & $16.21 \%$ \\
& $\mathbf{2 0 1 1}$ & $1.59 \%$ & $6.21 \%$ & $0.41 \%$ & $3.04 \%$ & $3.23 \%$ & $0.57 \%$ & $1.78 \%$ & $16.83 \%$ \\
& $\mathbf{2 0 1 2}$ & $1.27 \%$ & $4.77 \%$ & $0.52 \%$ & $3.48 \%$ & $3.04 \%$ & $0.68 \%$ & $1.52 \%$ & $15.28 \%$ \\
& $\mathbf{2 0 1 3}$ & $1.24 \%$ & $4.20 \%$ & $0.77 \%$ & $3.75 \%$ & $3.86 \%$ & $0.92 \%$ & $1.91 \%$ & $16.66 \%$ \\
\hline \multirow{6}{*}{ RCL } & $\mathbf{2 0 0 9}$ & $0.58 \%$ & $3.81 \%$ & $0.38 \%$ & $1.42 \%$ & $2.84 \%$ & $1.01 \%$ & $0.84 \%$ & $10.87 \%$ \\
& $\mathbf{2 0 1 0}$ & $0.44 \%$ & $3.11 \%$ & $0.52 \%$ & $1.94 \%$ & $2.90 \%$ & $0.87 \%$ & $0.76 \%$ & $10.53 \%$ \\
& $\mathbf{2 0 1 1}$ & $0.75 \%$ & $3.27 \%$ & $0.62 \%$ & $2.21 \%$ & $1.62 \%$ & $0.99 \%$ & $0.88 \%$ & $10.34 \%$ \\
& $\mathbf{2 0 1 2}$ & $0.67 \%$ & $3.35 \%$ & $0.53 \%$ & $2.24 \%$ & $1.75 \%$ & $1.03 \%$ & $0.83 \%$ & $10.39 \%$ \\
& $\mathbf{2 0 1 3}$ & $1.27 \%$ & $2.66 \%$ & $0.57 \%$ & $2.18 \%$ & $2.97 \%$ & $1.27 \%$ & $2.24 \%$ & $13.16 \%$ \\
\hline
\end{tabular}

Legend: Economic (EC), Environmental (EN), Labour Practices (LA), Human Rights (HR), Product Responsibility (PR), Society (SO), Strategy (ST)

Table 2. Parameters of the wordlist relative presence distributions

\begin{tabular}{|c|c|c|c|c|c|c|c|c|c|}
\hline Company & & EC & EN & HR & LA & PR & so & ST & Total \\
\hline & Min & $0.94 \%$ & $3.79 \%$ & $0.41 \%$ & $3.04 \%$ & $3.04 \%$ & $0.57 \%$ & $0.85 \%$ & $15.14 \%$ \\
\hline & Q1 & $1.24 \%$ & $4.20 \%$ & $0.50 \%$ & $3.47 \%$ & $3.09 \%$ & $0.68 \%$ & $1.52 \%$ & $15.28 \%$ \\
\hline & Median & $1.27 \%$ & $4.77 \%$ & $0.52 \%$ & $3.48 \%$ & $3.15 \%$ & $0.70 \%$ & $1.65 \%$ & $16.21 \%$ \\
\hline \multirow[t]{7}{*}{ CCL } & Q3 & $1.36 \%$ & $5.43 \%$ & $0.64 \%$ & $3.75 \%$ & $3.23 \%$ & $0.81 \%$ & $1.78 \%$ & $16.66 \%$ \\
\hline & Max & $1.59 \%$ & $6.21 \%$ & $0.77 \%$ & $4.97 \%$ & $3.86 \%$ & $0.92 \%$ & $1.91 \%$ & $16.83 \%$ \\
\hline & Mean & $1.28 \%$ & $4.88 \%$ & $0.57 \%$ & $3.74 \%$ & $3.27 \%$ & $0.74 \%$ & $1.55 \%$ & $16.02 \%$ \\
\hline & Std. Dev. & $0.23 \%$ & $0.97 \%$ & $0.14 \%$ & $0.73 \%$ & $0.34 \%$ & $0.13 \%$ & $0.41 \%$ & $0.78 \%$ \\
\hline & Min & $0.44 \%$ & $2.66 \%$ & $0.38 \%$ & $1.42 \%$ & $1.62 \%$ & $0.87 \%$ & $0.76 \%$ & $10.34 \%$ \\
\hline & Q1 & $0.58 \%$ & $3.11 \%$ & $0.52 \%$ & $1.94 \%$ & $1.75 \%$ & $0.99 \%$ & $0.83 \%$ & $10.39 \%$ \\
\hline & Median & $0.67 \%$ & $3.27 \%$ & $0.53 \%$ & $2.18 \%$ & $2.84 \%$ & $1.01 \%$ & $0.84 \%$ & $10.53 \%$ \\
\hline \multirow[t]{4}{*}{ RCL } & Q3 & $0.75 \%$ & $3.35 \%$ & $0.57 \%$ & $2.21 \%$ & $2.90 \%$ & $1.03 \%$ & $0.88 \%$ & $10.87 \%$ \\
\hline & Max & $1.27 \%$ & $3.81 \%$ & $0.62 \%$ & $2.24 \%$ & $2.97 \%$ & $1.27 \%$ & $2.24 \%$ & $13.16 \%$ \\
\hline & Mean & $0.74 \%$ & $3.24 \%$ & $0.52 \%$ & $2.00 \%$ & $2.42 \%$ & $1.03 \%$ & $1.11 \%$ & $11.06 \%$ \\
\hline & Std. Dev. & $0.32 \%$ & $0.42 \%$ & $0.09 \%$ & $0.34 \%$ & $0.67 \%$ & $0.15 \%$ & $0.64 \%$ & $1.19 \%$ \\
\hline
\end{tabular}

Legend: Economic (EC), Environmental (EN), Labour Practices (LA), Human Rights (HR), Product Responsibility (PR), Society (SO), Strategy (ST)

year period. In the three-year period 2009-2011 the two series show contrasting trends. The relative presence of the sustainability wordlist tends to increase in the information produced by $\mathrm{CCL}$, while it falls progressively in that of $\mathrm{RCL}$. In the reports referring to 2012, the first year following the shipwreck, an inversion of trends is recorded for both companies. The relative presence of the identified terms falls drastically in the information produced by $\mathrm{CCL}$ while, referring to $\mathrm{RCL}$, an (albeit slight) increase is recorded. Finally, in 2013, the differences appear to settle to a clear increase in the proposed indicator, thus highlighting a similar conduct by both companies.
Further considerations can be made by analysing the trend of the relative presence of the specific wordlist linked to the environment, for the two companies in question (Figure 2). In 2009, the relative presence of the environmental wordlist in the reports of the two companies coincides. In following years, up to 2012, the two patterns diverge: the indicator increases in the information produced by Carnival Corporation \& PLC, while for Royal Caribbean Cruises Ltd it does not seem to suffer serious oscillations, even though the trend does fall slightly. For both companies, in 2013 (the second report after the disaster), the relative presence of sustainability terminology 


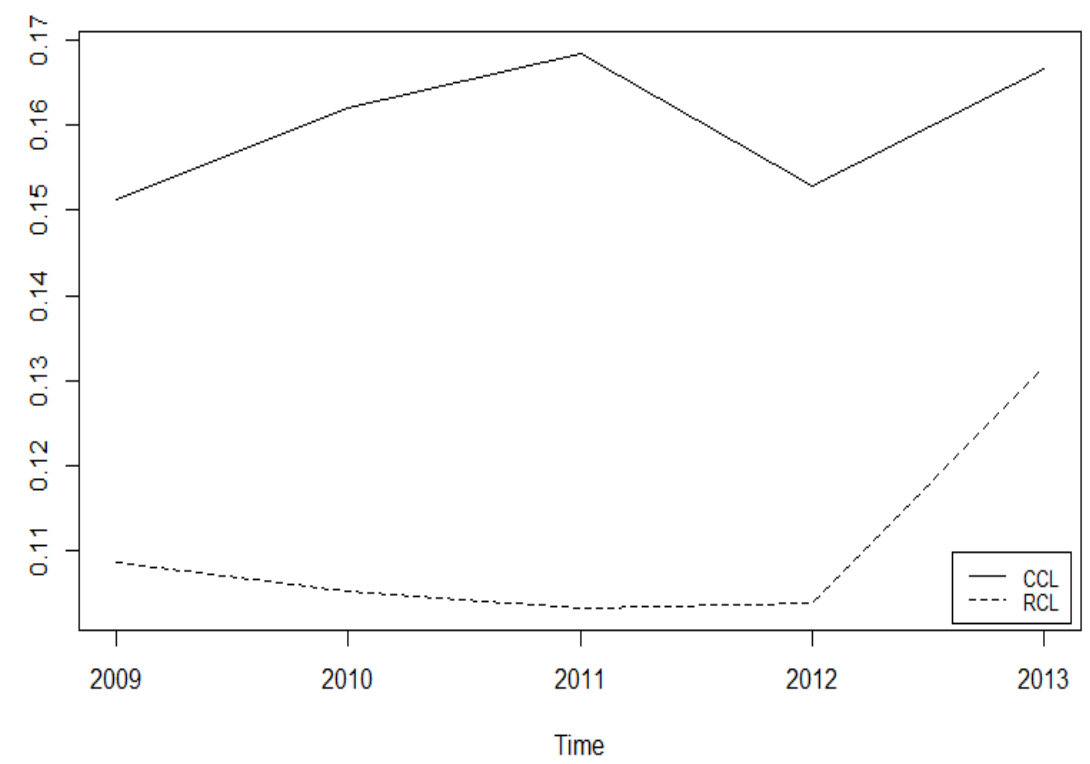

Figure 1. Overall trends of the wordlist relative presence

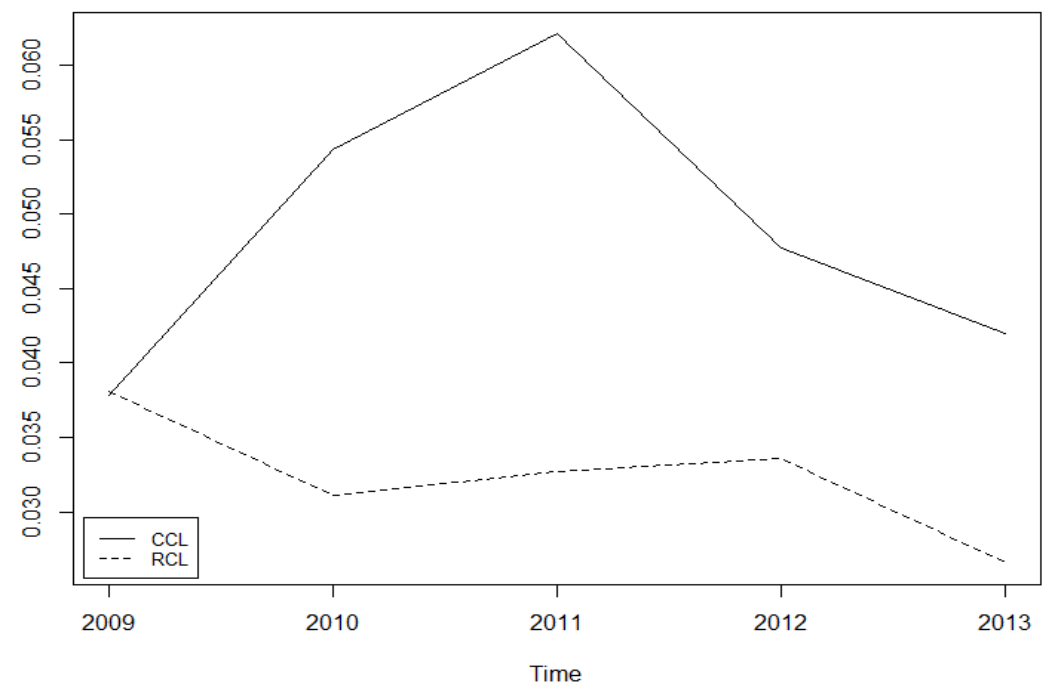

Figure 2. Relative presence of the environmental wordlist

drops, representing the lowest value in the last four years.

\section{Discussions}

Empirical data indicate that the sinking of Costa Concordia disaster affects the sustainability disclosure of the two analysed cruise companies. Even if $\mathrm{CCL}$ and RCL had a different disclosure behaviour before this negative event (the presence of the wordlist increases in $\mathrm{CCL}$ while it decreases in $\mathrm{RCL}$ from 2009 to 2011), both companies changed their level of disclosure in 2012 towards opposite directions.

The holding company of Costa Concordia (CCL) shows a significant drop, especially when compared to RCL, in the presence of the sustainability wordlist in the year of the disaster. Observed changes in the frequency of 
Sustainability disclosure and a legitimacy crisis: Insights from two major cruise companies.

the wordlist suggest that managers of CCL use sustainability reports to handle company legitimacy issues in a different way from what suggested by mainstream academic studies on legitimacy theory. In fact, results indicate that CCL does not react to a legitimacy threat, such as an industrial disaster, with an increase in the quantity of information disclosed. Moreover, a closer look into our results indicates that the decrease in company disclosure is mainly due to the reduction in environmental information, which represents the most relevant dimension. The categories or aspects of sustainability disclosure receiving more attention in order of importance are: environment, labour practices and product responsibility. With reference to CCL's main competitor, results indicate that the disaster is also linked to a change in the sustainability disclosure of this company. Since 2012, RCL begins using more terms of the relevant vocabulary (although to a limited extent), which then continue increasing in 2013.

On one hand, findings are in line with the strategic approach of legitimacy theory that considers reporting as a strategic tool used by managers to regain or maintain the legitimacy and reputation of a company. The changes in the level of disclosure of both $\mathrm{CCL}$ and $\mathrm{RCL}$ confirm that managers manipulate company disclosure in the attempt to affect recipients' perceptions. On the other hand, findings provide empirical evidence that regaining legitimacy does not automatically result in greater social and environmental disclosure.

With reference to this, the cruise context seems to differ from what previous studies have found in the case of oil \& gas companies, the airline industry and the mining sector. The energy company Total S.A., for example, tried to repair its legitimacy by increasing the sustainability disclosure in both 1999 and 2001 disasters (Cho, 2009). Likewise, three different airline companies have responded to separate airline disasters with considerable increases in CSR disclosure (Vourvachis, Woodward, Woodward, \& Patten, 2016) and the entire South African mining industry has evidenced an increase in disclosure levels following two major mining accidents (Coetzee \& van Staden, 2011).

\section{Conclusions}

From a theoretical point of view, this study contributes to the existing literature examining corporate disclosure reactions following threats to their social legitimacy, offering a detailed picture of what happens to sustainability disclosure of cruise companies when an industrial disaster occurs. The analysis provided highlights that, in this less investigated sector, legitimization may entail different disclosure behaviours. Thus, this study contributes to the existing literature confirming that reporting is a tool of legitimacy, but it also indicates that regaining legitimization after a disaster may be searched through a decrease in transparency of the company.

In addition, the great interest in environmental aspects and the relative scarce attention to social issues in the analysed companies in 2012 and 2013 reveal that cruise companies consider the institutional pressure of environmental authorities more important than the issues usually raised by the society and the local communities even in the case of an industrial disaster that involved a major loss of lives. The predominance of the environmental dimension in social reports is similar to that indicated by (Bonilla-Priego et al., 2014) with reference to cruise companies operating in normal conditions.

From a practical point of view, the results of this study can be useful for managers having to tackle similar situations. The observed corporate behaviours can be considered as an illustration for managers deciding whether to adopt a strategy based on the reduction of information or to react by increasing disclosure, where necessary providing details on the consequences of the event and on the corrective actions taken. Important implications also emerge for stakeholders who represent the users of sustainability reports. The reduction in the wordlist concerning the socalled triple bottom line suggests that stakeholders may not find adequate responses to their demand of transparency in the sustainability reports of companies facing with disastrous events. The behaviour of CCL is a clear warning in this sense. Similarly, findings advise international bodies and standard setters of sustainability reporting like the GRI 
that companies facing a legitimacy crisis might be tempted to reduce their transparency. In order to avoid this possibility, standard setters may evaluate to propose additional information requirements (like an add-on) or specific guidelines to be applied in the case of an industrial disaster caused by the organization.

This explorative research is not exempted from some limitations. First, it is not a statistical study but it just compares the practices of two companies, although they represent $65 \%$ of the cruise market. Another limit may lie in the objects of the analysis. The focus only on sustainability reports does not permit to understand if there is a general reduction in the wordlist presence considering all media (i.e. websites, social networks and press releases). Furthermore, a self-produced wordlist according to GRI guidelines does not consider some specific, sector-related terms. Future research may include an improved wordlist by inserting terms from other guidelines and a larger number of cases, also referring to other sectors affected by a similar industrial disaster, with the aim to generalise the conclusions of this study.

Possible explanations of the specific cruise companies' behaviour to be investigated in the future may relate to differences in the magnitude of the disasters investigated or to the fact that cruise companies are not generally considered to operate in environmentally sensitive industries. Thus, they are not exposed to social and ethical pressures like mining and oil companies. It is also possible that the market dominance of just two companies (i.e. duopoly) makes the cruise sector less sensitive to the need to repair their legitimacy.

\section{References}

Adams, C. A., Hill, W.-Y., \& Roberts, C. B. (1998). Corporate social reporting practices in Western Europe: legitimating corporate behaviour? The British Accounting Review, 30(1), 1-21.

Aerts, W., \& Cormier, D. (2009). Media legitimacy and corporate environmental communication. Accounting, Organizations and Society, 34(1), 1-27. doi:10.1016/ j.aos.2008.02.005
Ahmed Haji, A. (2013). Corporate social responsibility disclosures over time: evidence from Malaysia. Managerial auditing journal, 28(7), 647-676. doi:10.1108/MAJ-07-2012-0729

Aureli, S. (2017). A comparison of content analysis usage and text mining in CSR corporate disclosure. The International Journal of Digital Accounting Research, 17, 1-32. doi: 10.4192/1577-8517-v17 1

Aureli, S., Medei, R., Supino, E., \& Travaglini, C. (2016). Sustainability Disclosure after a Crisis: A Text Mining Approach. International Journal of Social Ecology and Sustainable Development (IJSESD), 7(1), 35-49. doi:10.4018/IJSESD.2016010102

Bebbington, J., \& Gray, R. (2001). An Account of Sustainability: Failure, Success and a Reconceptualization. Critical Perspectives on Accounting, 12(5), 557-588. doi:10.1006/cpac.2000.0450

Bebbington, J., Larrinaga, C., \& Moneva, J. M. (2008). Corporate social reporting and reputation risk management. Accounting, Auditing \& Accountability Journal, 21(3), 337-361. doi:10.1108/09513570810863932

Bonilla-Priego, M. J., Font, X., \& PachecoOlivares, M. D. R. (2014). Corporate sustainability reporting index and baseline data for the cruise industry. Tourism Management, 44, 149-160. doi:10.1016/ j.tourman.2014.03.004

Bouchet-Valat, M., \& Bastin, G. (2015). Package 'RcmdrPlugin. temis'.

Bresson, G., \& Logossah, K. (2011). Crowdingout effects of cruise tourism on stay-over tourism in the Caribbean: Non-parametric panel data evidence. Tourism Economics, 17(1), 127-158. doi:10.5367/te.2011.0028

Brida, J. G., \& Zapata, S. (2009). Cruise tourism: economic, socio-cultural and environmental impacts. International Journal of Leisure and Tourism Marketing, 1(3), 205-226. doi:10.1504/IJLTM.2010.029585

Brown, N., \& Deegan, C. (1998). The public disclosure of environmental performance information-a dual test of media agenda setting theory and legitimacy theory. Accounting and Business Research, 29(1), 21-41. doi:10.1080/00014788.1998.9729564

Butt, N. (2007). The impact of cruise ship generated waste on home ports and ports of call: A study of Southampton. Marine Policy, 
31(5), 591-598. doi:10.1016/j.marpol.2007. 03.002

Cho, C. H. (2009). Legitimation strategies used in response to environmental disaster: A French case study of Total SA's Erika and AZF incidents. European Accounting Review, 18(1), 33-62. doi:10.1080/0963 8180802579616

Cho, C. H., \& Patten, D. M. (2007). The role of environmental disclosures as tools of legitimacy: A research note. Accounting, Organizations and Society, 32(7), 639-647.

Cho, C. H., Patten, D. M., \& Roberts, R. W. (2006). Corporate political strategy: An examination of the relation between political expenditures, environmental performance, and environmental disclosure. Journal of Business Ethics, 67(2), 139-154. doi:10.1007/s10551-006-9019-3

Cloesen, U. (2003). Environmental impact management of ship based tourism to Antarctica. Asia Pacific Journal of Tourism Research, 8(2), 32-37. doi:10.1080/10941660308725466

Coetzee, C. M., \& van Staden, C. J. (2011). Disclosure responses to mining accidents: South African evidence. Paper presented at the Accounting Forum.

Cormier, D., Magnan, M., \& Van Velthoven, B. (2005). Environmental disclosure quality in large German companies: economic incentives, public pressures or institutional conditions? European Accounting Review, 14(1), 3-39. doi:10.1080/0963818042000 339617

Cruise Lines International Association - CLIA. (2014). The state of cruise industry in 2014. Retrieved from http://www.cruising.org/docs/ default-source/market-research/presscon ferencepresentation.pdf?sfvrsn $=0$

Cruise Market Watch. (2015). Cruise market watch announces 2014 cruise line market share and revenue projections. Retrieved from https://www.cruisemarketwatch.com/ articles/cruise-market-watch-announces2014-cruise-trends-forecast/

Dale, C., \& Robinson, N. (1999). Bermuda, tourism and the visiting cruise sector: Strategies for sustained growth. Journal of Vacation Marketing, 5(4), 333-339. doi:10.1177/135676679900500403

De Grosbois, D. (2016a). Corporate social responsibility reporting in the cruise tourism industry: A performance evaluation using a new institutional theory based model. Journal of Sustainable Tourism, 24(2), 245269.

De Grosbois, D. (2016b). Cruise Ship Labor: Cruise Line Disclosure of Employee Wellbeing-related Initiatives and Performance. Tourism in Marine Environments, 11(2-3), 201-208.

De Villiers, C., \& Van Staden, C. J. (2006). Can less environmental disclosure have a legitimising effect? Evidence from Africa. Accounting, Organizations and Society, 31(8), 763-781. doi:10.1016/j.aos.2006.03. 001

Deegan, C. (2002). Introduction: the legitimising effect of social and environmental disclosures-a theoretical foundation. Accounting, Auditing \& Accountability Journal, 15(3), 282-311. doi:10.1108/09513570210435852

Deegan, C., \& Islam, M. A. (2014). An exploration of $\mathrm{NGO}$ and media efforts to influence workplace practices and associated accountability within global supply chains. The British Accounting Review, 46(4), 397-415. doi:10.1016/j.bar.2014.10.002

Deegan, C., \& Rankin, M. (1996). Do Australian companies report environmental news objectively?: An analysis of environmental disclosures by firms prosecuted successfully by the Environmental Protection Authority. Accounting, Auditing and Accountability Journal, 9(2), 52-69. doi:10.1108/09513579610116358

Deegan, C., Rankin, M., \& Voght, P. (2000). Firms' disclosure reactions to major social incidents: Australian evidence. Accounting forum, 24(1), 101-130. doi:10.1111/14676303.00031

Dörre, J., Gerstl, P., \& Seiffert, R. (1999). Text mining: finding nuggets in mountains of textual data. Paper presented at the Proceedings of the fifth ACM SIGKDD international conference on Knowledge discovery and data mining.

Dowling, J., \& Pfeffer, J. (1975). Organizational legitimacy: Social values and organizational behavior. Pacific sociological review, 18(1), 122-136. doi:10.2307/1388226

Erftemeijer, P. L., Riegl, B., Hoeksema, B. W., \& Todd, P. A. (2012). Environmental 
impacts of dredging and other sediment disturbances on corals: a review. Marine Pollution Bulletin, 64(9), 1737-1765. doi:10.1016/j.marpolbul.2012.05.008

Feldman, R., \& Dagan, I. (1995). Knowledge Discovery in Textual Databases (KDT). Paper presented at the KDD.

Feldman, R., \& Sanger, J. (2007). Introduction to text mining: Cambridge University Press.

Font, X., Guix, M., \& Bonilla-Priego, M. J. (2016). Corporate social responsibility in cruising: Using materiality analysis to create shared value. Tourism Management, 53, 175-186.

Freeman, R. E., Rusconi, G., Signori, S., \& Strudler, A. (2012). Stakeholder theory (ies): Ethical ideas and managerial action. Journal of Business Ethics, 109(1), 1-2. doi:10.1007/s10551-012-1374-7

Fu-Ren, L., Lu-Shih, H., \& Fu-Tai, C. (2009). Discovering genres of online discussion threads via text mining. Computers \& Education, 52(2), 481-495. doi:10.1016/j. compedu.2008.10.005

Fuller, C. M., Biros, D. P., \& Delen, D. (2011). An investigation of data and text mining methods for real world deception detection. Expert Systems with Applications, 38(7), 8392-8398. doi:10.1016/j.eswa.2011.01.032

Gillet-Monjarret, C. (2015). Assurance of Sustainability Information: A Study of Media Pressure. Accounting in Europe, 12(1), 87105. doi:10.1080/17449480.2015.1036894

Harlow, W. F., Brantley, B. C., \& Harlow, R. M. (2011). BP initial image repair strategies after the Deepwater Horizon spill. Public Relations Review, 37(1), 80-83. doi:10.1016/j.pubrev.2010.11.005

He, W. (2013). Improving user experience with case-based reasoning systems using text mining and Web 2.0. Expert Systems with Applications, 40(2), 500-507. doi:10.1016/ j.eswa.2012.07.070

Hooks, J., \& van Staden, C. J. (2011). Evaluating environmental disclosures: The relationship between quality and extent measures. The British Accounting Review, 43(3), 200-213. doi:10.1016/j.bar.2011.06. 005

Hopwood, A. G. (2009). Accounting and the environment. Accounting, Organizations and Society, 34(3), 433-439. doi:10.1016/j.aos. 2009.03.002
Islam, A. M., \& Deegan, C. (2010). Media pressures and corporate disclosure of social responsibility performance information: a study of two global clothing and sports retail companies. Accounting and Business Research, 40(2), 131-148. doi:10.1080/00014788.2010.9663388

Islam, A. M., \& Islam, A. M. (2011). Environmental incidents in a developing country and corporate environmental disclosures: A study of a multinational gas company. Society and Business Review, $6(3)$, 229-248. doi:10.1108/174656811111 70984

Johnson, D. (2002). Environmentally sustainable cruise tourism: A reality check. Marine Policy, 26(4), 261-270. doi:10.1016/S0308-597X(02)00008-8

Jones, P., Hillier, D., \& Comfort, D. (2016). The Two Market Leaders in Ocean Cruising and Corporate Sustainability. International Journal of Contemporary Hospitality Management.

Jordan, E. J., Vogt, C. A., \& DeShon, R. P. (2015). A stress and coping framework for understanding resident responses to tourism development. Tourism Management, 48, 500-512. doi:10.1016/j.tourman. 2015.01.002

Klein, R. a. (2011). Responsible Cruise Tourism: Issues of Cruise Tourism and Sustainability. Journal of Hospitality and Tourism Management, 18(01), 107-116. doi:10.1375/jhtm.18.1.107

Kloptchenko, A., Eklund, T., Karlsson, J., Back, B., Vanharanta, H., \& Visa, A. (2004). Combining data and text mining techniques for analysing financial reports. Intelligent Systems in Accounting, Finance \& Management, 12(1), 29-41. doi:10.1002/ isaf.239

Kumar, B. S., \& Ravi, V. (2016). A survey of the applications of text mining in financial domain. Knowledge-Based Systems, 114, 128-147.

Lee, D., Hampton, M., \& Jeyacheya, J. (2015). The political economy of precarious work in the tourism industry in small island developing states. Review of International Political Economy, 22(1), 194-223. doi:10.1080/09692290.2014.887590

Lee, M. R., \& Blanchard, T. C. (2012). Community attachment and negative 
affective states in the context of the BP Deepwater Horizon disaster. American Behavioral Scientist, 56(1), 24-47. doi:10.1177/0002764211409384

Lester, J. A., \& Weeden, C. (2004). Stakeholders, the natural environment and the future of Caribbean cruise tourism. International Journal of Tourism Research, 6(1), 39-50. doi:10.1002/jtr.471

Liew, W. T., Adhitya, A., \& Srinivasan, R. (2014). Sustainability trends in the process industries: A text mining-based analysis. Computers in Industry, 65(3), 393-400. doi:10.1016/j.compind.2014.01.004

Loh, S., Wives, L. K., \& de Oliveira, J. P. M. (2000). Concept-based knowledge discovery in texts extracted from the web. ACM SIGKDD Explorations Newsletter, 2(1), 29-39.

Mahadeo, J. D., Oogarah-Hanuman, V., \& Soobaroyen, T. (2011). Changes in social and environmental reporting practices in an emerging economy (2004-2007): Exploring the relevance of stakeholder and legitimacy theories. Accounting Forum, 35(3), 158-175. doi:10.1016/j.accfor.2011.06.005

Matacena, A. (2010). Corporate social responsibility and accountability: some glosses. In M. G. Baldarelli (Ed.), Civil economy, democracy, transparency and social and environmental accounting research role (pp. 2-53). Milano: Mc Graw-Hill.

Michelon, G. (2012). Impression management and legitimacy strategies: The BP case. Financial reporting(4), 35-64. doi:10.3280/FR2012-004004

Milne, M., \& Adler, R. (1999). Exploring the reliability of social and environmental disclosures content analysis. Accounting, Auditing \& Accountability Journal, 12(2), 237-256.

Monfardini, P., Barretta, A. D., \& Ruggiero, P. (2013). Seeking legitimacy: Social reporting in the healthcare sector. Accounting Forum, 37(1), 54-66. doi:10.1016/j.accfor.2012. 11.001

Morhardt, J. E. (2010). Corporate social responsibility and sustainability reporting on the internet. Business Strategy and the Environment, 19(7), 436-452.

O'Donovan, G. (2002). Environmental disclosures in the annual report: Extending the applicability and predictive power of legitimacy theory. Accounting, Auditing \& Accountability Journal, 15(3), 344-371. doi:10.1108/09513570210435870

Özyurt, Ö., \& Köse, C. (2010). Chat mining: Automatically determination of chat conversations' topic in Turkish text based chat mediums. Expert Systems with Applications, 37(12), 8705-8710. doi:10.1016/j.eswa.2010.06.053

Page, K. (1987). The future of cruise shipping. Tourism Management, 8(2), 166-168.

Papathanassis, A., \& Beckmann, I. (2011). Assessing the 'poverty of cruise theory'hypothesis. Annals of Tourism Research, 38(1), 153-174. doi:10.1016/j.annals.2010.07.015

Prokofieva, M., \& Clark, C. (2014). The Effect of Press Visibility on Voluntary Disclosure: Country-Level Approach. Corporate Ownership and Control Journal, 11(2), 72-83.

Romero, C., Espejo, P., Zafra, A., Romero, J. R., \& Ventura, S. (2013). Web usage mining for predicting final marks of students that use Moodle courses. Computer Applications in Engineering Education, 21(1), 135-146. doi:10.1002/cae.20456

Romero, C., Ventura, S., \& García, E. (2008). Data mining in course management systems: Moodle case study and tutorial. Computers \& Education, 51(1), 368-384. doi:10.1016/j.compedu.2007.05.016

Salton, G., \& McGill, M. J. (1986). Introduction to modern information retrieval.

Sethi, S. P. (1979). A conceptual framework for environmental analysis of social issues and evaluation of business response patterns. Academy of Management Review, 4(1), 6374. doi:10.5465/AMR.1979.4289184

Skaalsvik, H. (2011). Service failures in a cruise line context: Suggesting categorical schemes of service failures. European Journal of Tourism Research, 4(1), 25.

Sorensen, P. (2012). The Marikana Tragedy. International Journal of Environmental Studies, 69(6), 871-873. doi:10.1080/ 00207233.2012 .734046

Suchman, M. C. (1995). Managing legitimacy: Strategic and institutional approaches. Academy of Management Review, 20(3), 571-610. doi:10.5465/AMR.1995.9508080331

Summerhays, K., \& De Villiers, C. J. (2012). Oil company annual report disclosure responses to the 2010 Gulf of Mexico oil spill. Jour- 
nal of the Asia-Pacific Centre for Environmental Accountability, 18(2), 103-130.

Tan, H., \& Lambrix, P. (2009). Selecting an ontology for biomedical text mining. Paper presented at the Proceedings of the Workshop on Current Trends in Biomedical Natural Language Processing.

Tilling, M. V. (2004). Some thoughts on legitimacy theory in social and environmental accounting. Social and Environmental Accountability Journal, 24(2), 3-7. doi:10.1080/0969160X.2004.9651716

Tregidga, H., Milne, M., \& Kearins, K. (2006). Organisational Legitimacy and Social and Environmental Reporting Research: The Potential Of Discourse Analysis. Paper presented at the 5th Australasian Conference on Social and Environmental Accounting Research, Wellington.

Uysal, A. K., \& Gunal, S. (2014). The impact of preprocessing on text classification. Information Processing \& Management, 50(1), 104-112.

Volo, S., \& Pardew, D. L. (2013). The Costa Concordia and similar tragic events: the mathematics and psychology of the loss and restoration of travellers' trust. Current Issues in Tourism, 16(2), 197-202. doi:10.1080/ 13683500.2012.715629
Vourvachis, P., Woodward, T., Woodward, D. G., \& Patten, D. M. (2016). CSR disclosure in response to major airline accidents: a legitimacy-based exploration. Sustainability Accounting, Management and Policy Journal, 7(1), 26-43.

Weeden, C. (2015). Legitimization Through Corporate Philanthropy: A Cruise Case Study. Tourism in Marine Environments, 10(3-4), 201-210. doi:10.3727/154427315X 14181438892810

Weiss, S. M., Indurkhya, N., Zhang, T., \& Damerau, F. (2010). Text mining: predictive methods for analyzing unstructured information: Springer Science \& Business Media.

Wood, R. E. (2000). Caribbean cruise tourism: Globalization at sea. Annals of Tourism Research, 27(2), 345-370. doi:10.1016/ S0160-7383(99)00073-0

Xiao Dong, S., Xiao Rong, W., \& Xue Gang, F. (2015). Cruise tourism seasonality: an empirical study on the North American market. Tourism Tribune, 30(5), 117-126.

Young, W., \& Tilley, F. (2006). Can businesses move beyond efficiency? The shift toward effectiveness and equity in the corporate sustainability debate. Business Strategy and the Environment, 15(6), 402-415. doi:10.1002/bse.510 